\title{
Xix. YüzyIL Sonlari ve Xx. YüzyIl Başlarinda Ordu Limani
}

ÖZ

Kemal SAYLAN

Karadeniz'in uluslararası ticarete açılmasıyla birlikte XIX. yüzyıldan itibaren Karadeniz liman şehirleri dünya ticaretiyle bütünleşmeye başlamıştır. Karadeniz kıyısında küçük bir liman kasabası olan Ordu da bu gelişmelerden etkilenmiş, önceleri içe kapank ekonomik faaliyetler sürdüren yöre, dış piyasalarla tanışarak ithalat ve ihracat yapar hale gelmiştir. Bu gelişme limandaki altyapı imkânlarının geliştirilmesini de zorunlu kılmış ve Ordu'da bir iskele inşa edilmiştir. Ayrıca Ordu'da kayıkçı esnafinın mağdur olduğu bazı sorunlar da yaşanmıştır. Bu çalışma yaşanan entegrasyon sürecinde Ordu Limanı'na dair bazı tespitler yapmayı amaçlamaktadır. Çalışmada Karadeniz' in uluslararası ticarete açlmasıyla birlikte ticaret potansiyeli artan Ordu Limanı'nın durumu ve kazanın büyümesine etkisi üzerinde durulacaktr.

Anahtar Sözcükler: Ordu, liman, ihracat, ithalat, kayıkçı esnafı

\section{AN EXAMINATION OF THE ORDU PORT BETWEEN THE LATE $19^{\text {th }}$ CENTURY AND EARLY 20 ${ }^{\text {th }}$ CENTURY}

\begin{abstract}
Blacksea port-cities have started catch up with the world trade since $19^{\text {th }}$ century especially with the introduction of international trade market of the Blacksea region. Being one of the Blacksea coast towns, Ordu was affected by these developments. Even though once being a closed economy, the region started to import and export after its integration with the global market. This integration made it necessary to develop infrastructure facilities, and a port was constructed in Ordu. Besides, boatman trades faced with some problems. This study aims to examine the role of Ordu port in this integration period. The study examines the situation of Ordu port, whose economic activity has increased after introduction Blacksea international trade and its impact on Ordu town.
\end{abstract}

Keywords: Ordu, port, export, import, boatman

* $\quad \ddot{g} r$. Gör., Gümüşhane Üniversitesi, Edebiyat Fakültesi Tarih Bölümü, GÜMÜŞHANE. kemalsaylan52@gmail.com 


\section{Giriş}

Karadeniz kıyıları antik çağlardan itibaren iskân edilen coğrafyalardan biri olmuştur. Antik çağın yaşam merkezi sayılan Akdeniz çevresindeki devletler dahi Karadeniz sahillerinde bir koloni kurmak için acımasız mücadelelere girmişlerdir. ${ }^{1} \mathrm{Bu}$ dönemde Karadeniz kıyılarında aralarında Ordu bölgesindeki Kotyora'nın da bulunduğu çok sayıda Grek koloni şehirleri kurulmuştur.

Ortaçağda Karadeniz'de başlıca egemen güç olan Bizans İmparatorluğu'nun zaafindan faydalanan veya o dönemdeki siyasi şartları kendi çıkarlarına göre kullanmayı başaran Cenevizliler, Karadeniz kıyılarında yeni koloni şehirleri kurarak buradaki ticaretten büyük kârlar elde etmişler ve bölgedeki varlıklarını XIV. yüzyıl boyunca korumuşlardır. ${ }^{2}$ XIV. yüzyıl sonlarından itibaren Karadeniz kıyılarında Trabzon hariç olmak üzere Osmanlı egemenliği tesis edilmeye başlandı. 1461 senesinde Trabzon'un da fethedilmesiyle birlikte Karadeniz' in güney kıyılarının tamamı Osmanlı hâkimiyetine geçmiş oldu. XV. yüzyıl boyunca yabancı gemilere kapalı olan ve XVII. yüzyılın sonlarına kadar bir Osmanlı iç denizi konumunda olan Karadeniz, uzun süre uluslararası ticarete kapalı kaldı. ${ }^{3}$ XVII. yüzyılın sonlarından itibaren uluslararası gelişmelere bağlı olarak ticari değişimler yaşanmaya başladı. 1774 tarihinde imzalanan Küçük Kaynarca Anlaşması'yla Rusya, Karadeniz'de Osmanlı Devletiyle birlikte söz sahibi oldu. Daha önceleri Karadeniz'de sadece Osmanlı gemileri ile ticaret yapabilen Ruslar, bundan sonra kendi gemileriyle de ticaret yapma başladılar. ${ }^{4}$ İngilizler ve Fransızlar ise yaptıkları anlaşmalarla Karadeniz ticaretinde imtiyazlar elde etmişlerdi. Bu gelişmeler sonucu Karadeniz uluslararası ticarete açılmış oldu. Osmanlı Devleti'nin 1774'te Rusya'ya, 1784'te Avusturya'ya, 1799'da İngiltere ve 1802'de Fransa'ya Karadeniz'de serbest ticaret yapma hakk1 vermesi bölgedeki siyasî ve iktisadî yapıyı önemli ölçüde etkiledi. ${ }^{5}$

Avrupa buharlı gemiler sayesinde XIX. yüzyılın başlarından itibaren deniz ulaşımında önemli bir aşama kaydetti. Buhar makineleri gemileri akıntılardan, gelgitlerden ve rüzgârlardan çekip çıkararak deniz taşımacılığının

John Boardman, The Greeks Overseas, London 1988, s. 225-245.

2 Mustafa Daş-Türkmen Töreli, "XIV. ve XIX. Yüzyıllarda Batılı Seyyahların Gözüyle Karadeniz Ticareti”, Tarih Boyunca Karadeniz Ticareti ve Canik-Samsun, Samsun 2013, s. 843.

3 Karadeniz'in kapalılığı konusunda bkz. Kemal Beydilli, "Karadeniz'in Kapalılığı Karşısında Avrupa Küçük Devletleri ve 'Miri Ticaret' Teşebbüsü’, Belleten, C: 55, S: 214, Aralık 1991, s. 687-755.

4 Murat Fidan, “1797-1800 Tarihlerinde Osmanl1-Rusya Arasında Karadeniz Üzerinden Gerçekleşen İhracat ve İthalat (87/5 Numaralı Rusya Ahkâm Defterine Göre)", Tarih Araştırmaları Dergisi, C: 28, S: 45, Ankara 2009, s. 83.

5 Necmettin Aygün, 'Osmanlı Devleti'nin Son Zamanlarında Karadeniz'in Güney Kesiminde İktisadî Faaliyetler”, Karadeniz Araştırmaları, C: 6, S: 23, Çorum 2009, s. 42. 
daha güvenli ve düzenli hale gelmesini sağladı. Deniz taşımacıllı̆ında köklü bir dönüşüm söz konusu oldu. ${ }^{6} \mathrm{Bu}$ gemiler denizlerdeki ticaret hacmini önemli ölçüde artırarak liman şehirlerine yeni bir soluk getirdi. Bu sayede Osmanlı kıyı şehirlerinin Avrupa'nın önemli limanlarıyla olan bağını güçlendi. Diğer taraftan Karadeniz'in uluslararası ticarete açılmasının ve Avrupalı devletlerle yapılan ticaret anlaşmalarının etkileri XIX. yüzyılda Karadeniz liman kentlerinde kendini göstermeye başladı. ${ }^{7}$ Uluslararası ticarette önemli paya sahip olmaya başlayan buharlı gemi taşımacılı̆̆ının bütün dünyada olduğu gibi Karadeniz'de de yaygınlaşması, Karadeniz liman şehirlerinin ticaret hacmini önemli ölçüde artırırdı. ${ }^{8}$

Anadolu şehirlerinin geleneksel üretim ilişkilerinin henüz değişmediği sanayileşmenin gerçekleştirilmediği bu döneminde şehirlerin ekonomik yapılarını belirleyen ana etken iç ve dış ticaretteki etkinlikleri olmakla birlikte, bazı kıyı kentlerinin belirgin bir gelişme göstermelerinin başlıca nedeni dış ticarette gösterdikleri atılım oldu. ${ }^{9}$ Küçük bir liman kasabası olan Ordu, bu dönemdeki gelişmelerden etkilendi. Trabzon sancağına bağlı bir kaza statüsünde olan Ordu'nun ekonomisi bu dönemde bir hayli canlandı. Daha önceleri kaza dâhilinde ekonomik faaliyetler sürdüren Ordu, artık dış piyasalarla tanışarak ithalat ve ihracat yapar hale geldi. ${ }^{10}$

Ordu kazası, bu dönemde Trabzon sancağına bağlı bulunuyordu. Bolaman, Perşembe, Ulubey, Hapsemana (Gölköy) ve Aybastı olmak üzere 5 nahiyesi vardı. ${ }^{11}$ Kazada yaşayan halkın bir bölümü ziraat ve ticaret ile bir bölümü de marangozluk, bakırcılık, kuyumculuk, çilingirlik, terzilik, kunduracılık, hakkâklık, balıkçılık, saraçlık, kayıkçılık, kalaycılık gibi zanaatlarla uğraşıyordu. ${ }^{12}$ Kaza dâhilinde başta findık ve mısır olmak üzere arpa, buğday,

6 İlhan Ekinci, "XIX. Yüzyılda Osmanlı Deniz Ticaretinde Değişim ve Tepkiler", Tarih İncelemeleri Dergisi, C: 21, S: 2, İzmir 2006, s. 37-54; Buharlı gemilerin Karadeniz’e girişi için bkz. Özgür Yılmaz, "Buharlı Gemi Çağında Karadeniz'de Avrupa Denizciliğı”, Karadeniz Sosyal Bilimler Dergisi, S: 25, Ankara 2014, s. 45-64.

7 Özgür Yılmaz, Batılı Seyyahlara Göre Trabzon (1808-1878), Karadeniz Teknik Üniversitesi Sosyal Bilimler Enstitüsü Yayımlanmamış Yüksek Lisans Tezi, Trabzon 2006, s. 98.

8 Murat Baskıcı, 1800-1914 Yıllarında Anadolu'da İktisadi Değişim, Ankara 2005, s. IX.

9 Musa Çadırcı, Tanzimat Döneminde Anadolu Kentlerinin Sosyal ve Ekonomik Yapısl, Ankara 1997, s. 360.

10 Kemal Saylan, 1868-1914 Döneminde Ordu Kazası, Karadeniz Teknik Üniversitesi Sosyal Bilimler Enstitüsü, Yayımlanmamış Yüksek Lisans Tezi, Trabzon 2007, s. 79-80.

11 Trabzon Vilayet Salnamesi 1318/1300 (TVS), s. 178-180. (Not: Bundan sonraki dipnotlarda Trabzon Vilayet Salnameleri, TVS kisalmasiyla ve salnamenin hicri basim y1lı miladiye çevrilerek verilecektir.) Kazanın genel nüfusu 91.290'1 Müslüman, 13.321'i Rum 9.497'is Ermeni ve 490'ı Protestan olmak üzere toplam 114.598 kişidir. TVS, 1900, s. 237; Kasaba nüfusu ise bu dönemde 10.000 civarındadır. Diplomatic and Consular Reports, Turkey. Report for the Year 1909-10 on the Trade and Commerce of the Trebizond Vilayet (TCTV), No: 4740, London 1911, s. 6. (Not: Bundan sonraki dipnotlarda yayınlanmış İngiliz konsolosluk belgeleri TCTV kısaltmasılla verilecektir.)

12 TVS, 1904, s. 133. 
çavdar, yulaf, fasulye, kendir, tereyağı, peynir, yün, bal, balmumu ve değişik hayvan derileri gibi ürünler üretilmekteydi. Merkeze bağlı bazı köylerde hasır süpürgesi ile gürgen ağacından kürek yapılmaktaydı. İmal edilen süpürge ve kürekler başta Rusya olmak üzere yabancı ülkelere gönderilmekteydi. ${ }^{13}$ İthal edilen iplik ve pamuk kazadaki tezgâhlarda işlenerek havlu ve peştamal haline getiriliyordu. Daha sonra bu havlu ve peştamallar kaza dâhilinde satışa çıkarılıyordu. ${ }^{14}$ Kasaba halkının büyük bir çoğunluğu ise ticaretle uğraşıyordu. ${ }^{15}$

Çalışmamızda Trabzon Vilayet Salnameleri, Başbakanlık Osmanlı Arşivi Belgeleri ve Yayınlanmış İngiliz Konsolosluk Raporlarından hareketle Karadeniz'in uluslararası ticarete açılmasıyla birlikte ticaret potansiyeli artan Ordu limanın durumu ve kazanın büyümesine etkisi üzerinde duracağız. Çalışmamızın ilk bölümünde iskele inşaatı, geliştirilmesi ve tamiriyle ilgili yürütülen çalışmalara değineceğiz. İkinci bölümünde limanda yaşanan sorunlar ve asayiş olayları hakkında bilgi vereceğiz. Üçüncü bölümde limanın ticaret hacmi üzerinde duracağız.

\section{1-Limanın Altyapısı İle İlgili Çalışmalar}

Ordu kasabası gelişmeye başlayıncaya ve burada bir liman inşa ettirilinceye kadar kazanın bağımlı olduğu en yakın liman, aynı zamanda doğal bir liman özelliği de taşıyan Vona idi. Bu liman, özellikle kış mevsiminde firtınaya tutulan gemilerin uğradığı bir barınaktı. Gün doğusu ve poyraz yönlerin esen rüzgârlara karşı gemileri koruduğundan kışın gemiler için önemli barınaklardan biri konumundaydı. Vona Limanı'nda kışlama süresince hiçbir gemi bir deniz kazasına maruz kalmazdı. ${ }^{16}$ Limanın bu özelliği dönemin yazarları tarafından da belirtilmektedir. Dönemin yazarlarından Şemsettin Sami, Kamus'ul Alam adlı eserinde kasabaya bir saat kadar uzaklıkta bulunan ve iyi demir tutan tarihi bir liman olduğunu ayrıca kasaba ticaretine katkıda bulunduğunu belirtmektedir. ${ }^{17}$ Şakir Şevket de buranın, Sinop'tan Trabzon'a kadar uzanan bölgede gemicilerin firtına esnasında sığınabildiği iki limandan biri olduğunu söylemektedir. ${ }^{18}$ Ona göre limanın tek eksiği ticaret potansiyeline sahip olmamasıdır. ${ }^{19}$ IV. Ordu Komutanı Mehmed Zeki Paşa, II. Abdülhamid'e sunduğu raporda Samsun, Giresun ve Trabzon limanlarının korunması ve IV. Ordu'nun ihtiyacı olan mühimmatın iç bölgelere sevk edilmesi için Vona Limanı'nın bir üst olmasını teklif etmektedir. Bunun için

\footnotetext{
TVS, 1871, s. 247; TVS, 1903, s. 250-251.

TVS, 1903, s. 250-251.

Şakir Şevket, Trabzon Tarihi, Haz: İsmail Hacıfettahoğlu, Ankara 2001, s. 92.

TVS, 1888, s. 253; BOA, Y. PRK. DH, 1/81, 07 R 1302/25 Aralık 1884.

Şemseddin Sami, Kamus'ul Alam, C: 2, Ankara 1996, s. 825-826.

Diğeri Polathane Limanı'dır. Şakir Şevket, a.g.e, s. 56.

Şakir Şevket, a.g.e, s. 56.
} 
limanın güçlenmesinin şart olduğunu belirtmektedir. ${ }^{20}$

Bir ara Trabzon Vilayet Meclisi'nde Ordu, Fatsa ve Ünye kazalarının birleştirilerek yeni bir sancak oluşturulması tartışıldı. Limanın bulunduğu Perşembe kasabasının da öneminden dolayı sancağın merkezi olması düşünüldü. ${ }^{21}$ Ancak Vona Limanı, ehemmiyetli bir liman olsa da kaza merkezi olan Ordu kasabasına denizden 12 mil mesafedeydi. Ayrıca limanı karadan kasabaya bağlayan bir yol bulunmuyordu. Bu durum limanın gelişmesini engelliyordu. Diğer taraftan 1884'te Ordu-Sivas şosesinin tamamlanması Ordu kasabasının iç bölgelerle olan ticaret hacminin artmasını sağlamıştı. ${ }^{22} \mathrm{Bu}$ yol, Ordu kasabası ile Sivas ve mülhakatını birbirine bağlıyordu. ${ }^{23}$ Yeni yapılan yol sayesinde hem Ordu kazasının iç bölgelerinde hem de Sivas vilayeti dâhilinde üretilen ürünler kıyıya getirilerek ihraç edilme imkânına kavuşmuş oldu. Böylece Ordu kasabasının ticari önemi daha da arttı.

Ancak bu dönemde Ordu kasabasında gerek kaza dâhilinden gerekse Sivas vilayetinden gelen malların yüklenebileceği ve büyük gemilerin yanaşabileceği bir liman yoktu. Kasabaya gelen gemiler açıkta demirliyor, yükleme-boşaltma işlemi kayıkçılar vasıtasıyla gerçekleştiriliyordu. Bu sorunun halledilmesi amaciyla Ordu Belediyesi tarafindan sahile ahşap bir iskele yapılmasına karar verildi. İskelenin yapım çalışmalarına Ordu-Sivas şosesinin tamamlandığı tarih olan 1884 senesinde başlandı. Belediye, maliyetinin 21.500 kuruş tutacağı düşünülen iskelenin yapım masraflarını tek başına karşılayamayacağını düşündüğü için Dâhiliye Nezareti'nden yardım istedi. Dâhiliye Nezareti, iskelenin 4 sene içinde bitirilmesini isteyerek yapım ve tamir masraflarının bu süre içinde iskeleden yapılan ticaretten alınan vergilerden elde edilen gelirden karşılanmasına karar verdi. İskelenin inşası süresince vergi alınacak mallar ve miktarları şöyledir: ${ }^{24}$

\footnotetext{
20 BOA. Y.PRK. ASK, 53/101, 19 B 1306/21 Mart 1889.

21 BOA, Y. PRK. DH, 1/81, 07 R 1302/25 Aralık 1884; Ayrıca ayrıntılı bilgi için bkz. Ayhan Yüksel, "Vona'nın Sancak Merkezi Yapılma Girişimi (1885)”, Doğu Karadeniz Araştırmaları, İstanbul 2005, s. 115-118.

22 Şemseddin Sami, a.g.e, s. 825-826; Ali Ata Yiğit, "Tarihi Süreci Işığında Kelkit Vadisi ve Sivas-Şebinkarahisar-Giresun Ticaret Yolu", Orta Karadeniz Kültürü Sempozyumu, Ankara 2005, s. 493, Ayrıca ayrıntılı bilgi için bkz. Saylan, a.g.t, s. 111.

23 BOA, DH. ID, 52/6, 07 Ca 1309/8 Ocak 1892.

24 BOA, I. ŞD, 69/4086, 16 L 1301/9 Ağustos 1884; Ayrica bkz. Adnan Yıldız, Osmanlı Belgelerinde Ordu, İstanbul 2013, s. 158.
} 
Tablo 1: Vergi Alinacak Mallar ve Miktarları

\begin{tabular}{|l|l|l|l|}
\hline \multicolumn{1}{|c|}{$\begin{array}{c}\text { Malın } \\
\text { Cinsi }\end{array}$} & $\begin{array}{c}\text { Vergi } \\
\text { Miktarı } \\
\text { (para) }\end{array}$ & \multicolumn{1}{|c|}{$\begin{array}{c}\text { Malın } \\
\text { Cinsi }\end{array}$} & $\begin{array}{c}\text { Vergi } \\
\text { Miktarı } \\
\text { (para) }\end{array}$ \\
\hline Fasulye Çuvalı & 2 para & Demir Kantarı & 5 para \\
\hline Mısır Çuvalı & 2 “ & Kendir Balyası & 10 “ \\
\hline Buğday Çuvalı & 2 “ & Süpürge Balyası & 10 “ \\
\hline Arpa Çuvalı & 2 “ & Balmumu Balyası & 10 “ \\
\hline Alaf Çuvalı & 2 “ & Yün Balyası & 10 “ \\
\hline Kendir Tohumu Çuvalı & 2 “ & Üstübi Balyası & 10 “ \\
\hline Ceviz Çuvalı & 2 “ & Gön Yağı Balyası & 10 “ \\
\hline Un Çuvalı & 2 “ & Amerikan Bezi Balyası & 40 “ \\
\hline Şeker Çuvalı & 5 “ & Tahi Çival Balyası & 40 “ \\
\hline Kahve Çuvalı & 5 “ & Balık yağı Varili & 20 “ \\
\hline Sabun Çuvalı & 5 “ & Rakı Varili & 20 “ \\
\hline Kına Çuvalı & 5 “ & Şarap Varili & 20 “ \\
\hline Gaz Sandığı & 2 “ & İspirto Varili & 40 “ \\
\hline Çelik Sandığ1 & 5 “ & Gaz Yağı Fıçısı & 20 “ \\
\hline Yumurta Sandı̆ı & 20 “ & Malikonda Dengi & 20 “ \\
\hline Cam Sandığı & 5 “ & Teneke Yağı & 2 “ \\
\hline Karakında Sandığı & 5 “ & Koyun ve Keçi (Her Birinden) & 5 “ \\
\hline Elma Sandığı & 10 “ & $\begin{array}{l}\text { İthal Edilen Tomruk } \\
\text { (Her Birinden) }\end{array}$ & 20 “ \\
\hline Boş Sandık & 5 “ & İhraç Edilen Taş (Her Birinden) & 1 “ \\
\hline $\begin{array}{l}\text { Büyük Latan } \\
\text { (Her Yüzünden) }\end{array}$ & 50 “ & Küçük Lata (Her Yüzünden) & 30 “ \\
\hline $\begin{array}{l}\text { Çam Tahtasının Çifte } \\
\text { Koğuşu (Her Yüzünden) }\end{array}$ & 50 “ & $\begin{array}{l}\text { Çam Tahtasının Tek Koğuşu } \\
\text { (Her Yüzünden) }\end{array}$ & 30 “ \\
\hline
\end{tabular}

Alınan karar üzerine iskele yapımına başlandı. Ancak dört sene sonunda maddi sorunlar nedeniyle iskelenin inşaatı tamamlanamadı. Bu süre zarfinda iskelenin inşası için 27.000 kuruş, limana ait yerlerin tamiri için 5.360 kuruş olmak üzere toplam 32.360 kuruş harcanmıştı. Ancak vergilerinden toplanan gelir sadece 18.170 kuruştu. İskelenin tamamlanabilmesi için 14.190 kuruşa daha ihtiyaç vardı. Bunun üzerine Ordu Belediyesi, Dâhiliye Nezareti'ne yazı yazarak iskelenin inşasında ve liman tamirinde kullanılmak üzere vergilerin 4 sene daha devam etmesini istedi. ${ }^{25} \mathrm{Bu}$ isteği değerlendiren Dâhiliye Nezareti, iskelenin inşaatı için alınan verginin 27.000 lira tamamlanıncaya kadar devam etmesine, tamiratların ise belediye tarafından karşılanmasına karar verdi. ${ }^{26}$

$25 B O A, S D, 1841 / 29,09$ Za 1321/17 Şubat 1904.

26 BOA, DH. MKT, 1510/38, 20 N 1305/31 Mayıs 1888. 
Kaynak sorununun halledilmesi üzerine çalışmalar kaldığı yerden devam etti ve iskele inşaatı tamamlandı. Limanın ticaret potansiyelinin artması üzerine 1892 tarihinde liman içerisinde bir liman dairesi ve bir acentehane yapılmasına karar verildi. Yapılan binaların inşaat masrafları, Taşbaşı Mahallesi'nin Kumluk Mevkii'nde kayık çekmek üzere önceden beri terk edilmiş halde bulunan $6.000 \mathrm{~m}^{2}$ lik arazinin yaklaşı $1.020 \mathrm{~m}^{2}$ 'lik kısmı satılarak karşılandı. ${ }^{27}$

Daha sonraki tarihlerde limanın iyileştirme çalışmalarına devam edildi. Örneğin, ahşap iskelenin aradan geçen 10 yıl içinde çürümeye başlaması ve ihtiyacı karşılamaması üzerine 1894 senesinde tahta iskele yerine demir iskele yapılmasına verildi. ${ }^{28}$ İskelenin masrafının karşılanması hususu Trabzon vilayetiyle görüşüldü ve Şûra-yı Devlet tarafından mazbata hazırlandı. ${ }^{29}$ Ancak demir iskelesi yapım kararı hayata geçirilemedi. Nitekim 1907 tarihli İngiliz konsolosluk raporunda Ordu'ya maliyeti 25.000 sterlin olan bir iskelenin yapılmasının planlandığ 1 ifade edilmektedir. ${ }^{30} 1901$ senesinde liman dairesi ve bir acentehane binalarının tamiri için 10.000 kuruş harcandı. ${ }^{31}$

\section{2-Limanda Yașanan Bazı Sorunlar}

XX. yüzyıl başlarına kadar Karadeniz kentlerindeki birçok limanda büyük gemilerin yanaşabilecekleri iskeleler bulunmamaktaydı. Ordu Limanı da bu limanlar arasında yer almaktaydı. Bu nedenle açıkta demirleyen gemilerdeki yükler gulet, kotra ve mavna gibi teknelerle boşaltılmakta veya yüklenmekteydi. 1902 senesinde Ordu Limanı'na kayıtlı 32 büyük gemi, 39 küçük gemi, 61 mavna $^{32}, 50$ preme $^{33}$ ve 3 çapar $^{34}$ olmak üzere toplam 185 tekne bulunuyordu. ${ }^{35}$

Limana bağlı kayık sayısının fazla olması zaman zaman liman yönetimi ve belediye ile kayıkçı esnafin sorunlar yaşamasına neden oluyordu. Kayıkçı esnafinın karşılaştığı sorunların başında kayık, mavna ve küçük gemilerin karaya çekildikleri çekek yerlerinin satılması geliyordu. Örneğin, 1887 senesinde Ordu Belediyesi'nin kayıkçıların çekek yerlerini satışa çıkarması ve

27 BOA, DH. MKT, 1982/75, 10 M 1310/4 Ağustos 1892.

28 BOA, ŞD, 1849/14, $11 \mathrm{R}$ 1314/20 Ağustos 1896.

29 BOA, ŞD, 1849/14, 11 R 1314/20 Ağustos 1896; Ayrıca bkz. Adnan Yıldız, a.g.e, s. 182.

30 TCTV, No: 4315 , s. 5.

31 BOA, BEO, 1728/129541, 20 C 1319/4 Eylül 1901.

32 Mavna, gemilere yük taşıyan kürekli ve motorlu büyük kayıklara verilen isimdir. Ferid Devellioğlu, Osmanlıca-Türkçe Ansiklopedik Lûgat. Aydın Kitabevi, Ankara 2010, s. 679.

33 Preme, uzun, dar ve hafif olup bir, iki üç, dört çifte gibi kürek sayılarının arttığı ölçüde büyüyen oldukça zarif yapılı kayıklara verilen isimdir. 18. Yüzyıldan sonra premelere piyade denilmiştir. Murat Uluskan, "Üsküdar Kayıkçıları (XVIII. Yüzyıl)”, Üsküdar Sempozyumu VBildiriler, (1-5 Kasım 2007), C: 1, Üsküdar Belediyesi Yayınları, İstanbul 2008, s. 246.

34 Çapar, Kamus-1 Bahrî'de "Samsun ve civarı sevahilinde icra-yı ticaret eden ve takadan büyük olup kürek ve bir aşırma yelken ile müteharrik bulunan kayıklardır" şeklinde tarif edilmektedir. Sezar Atmaca, "Çapar Kaybolan Tekne", Atlas, S: 231, Haziran 2012, s. 56-60.

35 TVS, 1902, s. 490. 
buraları Ordu'nun ileri gelenlerine satarak bina yapılmasına izin vermesi üzerine kayıkçı esnafı, 31 Ocak 1888 tarihinde Trabzon vilayetine dilekçe yazarak şikâyette bulunmuşlardı. Durumun Dâhiliye Nezareti'ne bildirilmesi üzerine nezaret bu yerlerin satışına son verilmesini istemiş ve gelen bu emir üzerine çekek yerlerinin satışına son verilmişti. ${ }^{36}$

$\mathrm{Bu}$ sorun daha sonraki tarihlerde tekrar gündeme geldi. 1900'lü yılların hemen başında kayıkçılar, Dâhiliye Nezareti'ne Ordu İskelesi'ndeki deniz vasıtalarının çekek mahallerinin belediye başkanı tarafından satıldığı, Telgraf ve Posta İdaresi ile Ali Paşa'nın binası arasında bulunan çekek yerine Fakulidi Yorgi Efendi tarafindan bina inşa edilmeye başladığıyla ilgili şikâyette bulundular. Şikâyet dilekçelerinde, çekek mahallerine belediye tarafından bina inşasına izin verildiği, bu yüzden kayıkların muhafazası için çekek yeri kalmadığ 1 ifade edilmekteydi. Kayıkçılar, belediye tarafından kendilerine çekek yeri olarak Gazhane mevkiinin gösterildiğini, buranın liman haricinde olması nedeniyle kendileri için uygun olmadığını söylüyorlardı. Bu nedenle, Ali Paşa ve Yorgi Efendi tarafından bina inşa edilecek arsa ile İvan Ağa'nın mağazası önünde bulunan Protestan mektebi civarındaki arsaların, çekek yeri olarak kendilerine tahsis edilmesini istiyorlardı. Kayıkçı esnafının şikâyetini değerlendiren Dâhiliye Nezareti, daha önce çekek mahalli olan yerlere katiyen müdahale edilmeyip, olduğu gibi bırakılarak gerek halkın ve gerekse hazinenin zarardan korunması yönünde karar verdi. ${ }^{37}$

1914 senesinde rüsumat binasının çekek yerlerinin üzerine yapılması düşüncesi yine şikâyetlere neden oldu. Bunun üzerine Bâb-1 Âlî, Samsun Merkez Liman Başkanlı̆̆ı'na yazı yazarak Ordu Kasabası'nda rüsumat binası inşası düşünülen çekek yeri ve muhtelif havalarda kayıkların çekilmesi yahut denize indirilmesi için başka münasip bir yer olup olmadığının araştırılmasını istedi. Samsun Merkez Rüsumat Başkanlığı istenilen tahkikatı yaparak durumu Bâb-1 Âlî’ye rapor halinde sundu. Sunulan raporda bina inşası düşünülen yerin önemli bir çekek mevkii olduğu, buna karşılık gösterilen Gazhane sahilinin şehrin dışında bulunduğu, buranın çok dalgalı olması nedeniyle sert havalarda küçük deniz araçlarının güvenliğini temin edemeyeceği ifade ediliyordu. Çözüm olarak da çekek yerinin çevresinde rüsumat binası inşasına elverişli ve istimlak edilebilir özel mülkiyetlerin bulunduğu, bu yerlerin kamulaştırılarak sorunun halledilebileceği, deniz ticaretinin gelişmesi için sarf edilen mesainin semeresini vermesi ve deniz esnafının korunması için inşası düşünülen rüsumat binası için başka münasip bir yerin istimlak edilmesi gerektiği ve çekek yeri için verilen ruhsatın iptal edilmesinin uygun olacağ1 belirtiliyordu. Bunun üzerine Bâb-1 Âlî, durumu Bahriye Nezareti'ne bildirerek rapor doğrultusunda gereğinin yapılmasını isteyerek sorunu çözüme

\footnotetext{
36 BOA, DH. MKT, 1482/26, 18 Ca 1305/2 Mart 1888.

37 BOA, DH. MKT, 2367/105, 04 Ra 1318/1 Ağustos 1900.
} 
kavuşturdu. $^{38}$

Limanda zaman zaman asayiş olayları da yaşanmaktaydı. Bunlardan biri Sarı Mehmetoğlu Nezir'in limana kayıtlı kayıkçı esnafını itaatsizliğe teşvik ederek ayaklandırma girişimidir. Sarı Mehmetoğlu Nezir, önceden kethüda olarak tayin edilen ve kethüdâlık adının kalkması üzerine daha sonra değnekçi unvanı verilen bir kişiydi. İskelede bulunan 43 adet kotra, mavna ve kayıkların nöbet usulüyle nakliyat yapmaları görevini yürütüyordu. Sarı Mehmetoğlu Nezir, 1909 senesinde "Şimdi hürriyet vardır. Liman resmi vermeyeceğiz, liman idaresini tanımayacağız." gibi sözlerle limana kayıtlı 5 kayıkçıyı ayaklandırarak liman idaresine karşı itaatsizliğe teşvik etti. Nezir ve arkadaşları kayıkçılara, önceden her yolcudan 5 kuruş alınan götürü ücretin 25 kuruşa çıkarılmasını teklif ediyordu. Nezir ile kayıkçı Kısapanayotoğlu Kasti, Yorgi, Hakkı ve İbrahimoğlu Tevfik adlı kimseler deniz üzerinde yolculardan tutturabildikleri kadar ücret almaya başladılar. Diğer kayıkçılar, mahalli liman reisinin bu duruma müsaade etmesinden rahatsıdılar. Bu nedenle liman reisi hakkında vilayete şikâyette bulunmuşlardı. Ancak bu konu hakkında valilik tarafından bir şey yapılmamıştı. Bu kez Dersaadet Liman Dairesi Başkanlığı'ndan Ordu liman reisinin değiştirilmesini istediler. Bu şikâyetler üzerine Dersaadet Liman Dairesi Başkanlığı Ordu liman reisinin değiştirilmesine karar verdi. Yerine yeni bir liman reisi atayarak Sarı Mehmetoğlu Nezir, Kasti, Yorgi, Hakkı ve Tevfik'in kanuna aykırı hareketlerinden dolayı haklarında gerekli işlemlerin yapılmasını ve Ordu Kaymakamlığı'ndan da liman vergisinin tahsili konusunda liman reisine yardımcı atamasını istedi. ${ }^{39}$

Limanda yaşanan asayiş olaylarından diğeri 1892 senesinde limana demirleyen Heskon adlı İngiliz şirketine ait Sis adlı vapurun süvarilerinden Kurukson'un limanda kayıkçılık yapan Sarı Mehmetoğlu Abdi’yi öldürmek amacıyla tüfekle kurşun atması olayıdır. Olay üzerine Kurukson tutuklanarak hakkında ne tür bir işlem yapılması gerektiği ile ilgili Dâhiliye Nezareti'ne yazı yazılmıştır. ${ }^{40}$ Dâhiliye Nezareti'nden verilen cevapta gemi kaptanın ifadesinin alınması için kendisine yazı gönderilmesi ve tahkikat sonuçlanıncaya kadar Kurukson'un tutuklu olması gerektiğinden durumun Trabzon konsolosuna bildirilmesi, Ordu'da konsolos bulunmadığı için de en yakınındaki Trabzon Mahkemesi'nde tercüman huzurunda ifadesinin alınması istenmiştir. Yazıda ayrıca, Kurukson'un kanunen tutuklanması gerektiği belirtilmiş ancak bu durumun vapurun hareketine mani olacağı ifade edilmiştir. $\mathrm{Bu}$ nedenle konsolosunun gerekirse kefaletle serbest birakılması tavsiye edilmiştir. ${ }^{41}$

Kaçakçılık olayları limanda sorunlar yaşanmasına neden olmuştur. $\mathrm{Bu}$

\footnotetext{
BOA, BEO, 4291/321771, 17 B 1332/7 Haziran 1914.

BOA, DH. MKT, 2731/34, 15 M 1327/6 Şubat 1909.

BOA, DH. MKT, 1933/83, 17 Ş 1309/17 Mart 1892.

BOA, DH. MKT, 1938/13, 29 \$̧ 1309/29 Mart 1892.
} 
olayların Bahriye Nezareti'ne kadar intikal ettiği görülmektedir. Örneğin, Hakkı isimli bir kayıkçı Ordu kasabası çevresinde bulunan Melet ve Ebulhayr iskelelerinin Ordu İskelesi'ne bağlı olması nedeniyle liman vergisine tabi bulunduğu halde bu vergiyi ödememiştir. Bunun üzerine Ordu Liman Dairesi Başkanlığı tarafindan kendisine 190 kuruş para cezası verilmiştir. Ancak bu kişinin bu cezayı ödememesi, kaçakçılık yapmaya devam etmesi ve liman nizamına uymaması üzerine liman idaresi bu kişi hakkında Bahriye Nezareti'ne şikâyette bulunmuştur. Bu şikâyet üzerine nezaret, kayıkçı Hakkı'nın yaptığı kanun dışı hareketlerin cezasını çekmesi, bu konuda Ordu kaymakamlığının liman idaresine yardımcı olması gerektiği yönünde Dâhiliye Nezareti'ne yazı yazmıştır. ${ }^{42}$

Limanda yaşanan sorunlardan bir diğeri de I. Dünya Savaşı döneminde değişik tarihlerde limanın Rus torpidolarının saldırısına maruz kalmasıdır. Osmanlı Devleti savaşa girdikten sonra Rus torpidoları Ordu ve Vona limanları açıklarında dolaşarak zaman zaman bu iki limanı bombardımana tabi tutmuşlardır. Örneğin, 1915 tarihinde Rus donanmasına ait bir torpido Vona Hükümet Konağı'nı bombalayarak Vona Limanı açıklarında Polathane İskelesi'ne kayıtlı bir kayığı batırmış ve mürettebatını da esir etmişti. ${ }^{43} 1916$ senesinde Ordu ve Vona limanları düşman torpidosu tarafindan bombardıman edilmişti. ${ }^{44} 1917$ senesinde ise bir Rus torpidosu Vona Limanı'na girdikten sonra silah zoruyla orada bulunan kayıklardaki yükleri boşaltarak el koymuştu. ${ }^{45}$ Yine aynı tarihte Fatsa tarafindan Vona Limanı'na gelen bir düşman torpidosu Ordu kasabasının doğu tarafindaki Ebulhayr Mevkii'nde bulunan kayıkları ve daha sonra kasabanın batı tarafindan gelen kruvazör ve motorbotlarla Ordu kasabasına toplam 101 adet top mermisi atmışlardı. Atılan bu top mermilerinden Ordu Limanı, hapishane, jandarma, rüsumat, adliye ve hastane gibi devlet daireleri ile cami, kilise gibi ibadethaneler de dâhil olmak üzere toplam 37 bina hasar görmüştï. ${ }^{46}$

\section{3-Limanın Ticarî Potansiyeli}

Karadeniz'in uluslararası ticarete açılmasılyla birlikte Avrupalı şirketlere ait gemiler Karadeniz'deki Trabzon, Samsun gibi büyük limanlara uğramaya başladılar. Hâkim olduğu karasulardaki gelişmelere ayak uydurmak isteyen Osmanlı Devleti de kurduğu deniz şirketleri vasıtasıyla Karadeniz kıyılarında ticari faaliyetlerini artırmaya çalıştı. Başlangıçta Osmanlı deniz şirketleri de Avrupalı şirketler gibi sadece Trabzon, Samsun, Giresun gibi büyükçe limanlara uğruyordu. Ancak bu durum gemilerinin eski olması, tonajlarının düşük

BOA, DH. H, 41/26, 23 Ra 1329/23 Nisan 1911.

43 BOA, DH. EUM.5.Şb, 17/13, 07 Za 1333/16 Ekim 1915.

44 BOA, DH. ŞFR, 525/78, 04 Temmuz 1332/17 Temmuz 1916.

45 BOA, DH. EUM.6.Şb, 17/84, 29 N 1335/19 Temmuz 1917.

46 BOA, DH. ŞFR, 555/93, 20 Mayıs 1333/20 Mayıs 1917. 
olması vb. gibi nedenler Osmanlı gemi acentasının ${ }^{47}$ diğer Avrupa bandralı gemi acentalarından çok daha az kar elde etmesine neden oluyordu. Osmanlı gemi acentesi bu açığını kapatmak için ve yerel yönetimlerin de taleplerini göz önünde bulundurarak zamanla Avrupalı acentaların sefer güzergâhına dâhil etmediği küçük limanlara düzenli olarak uğramaya başladı. ${ }^{48}$ Böylece bir zamanlar sadece küçük yerli gemi ticaretine sahne olan Ordu'nun da içinde bulunduğu küçük limanlar zamanla yabancı denizyolu şirketlerinin sefer listelerine girdi. ${ }^{49}$

XIX. yüzyılın ikinci yarısından itibaren Fevâid-i Osmaniye şirketine ait gemilerin Ordu Limanı'na düzenli olarak uğraması kısa sürede yabancı şirketlere ait gemilerin de burayı güzergâhlarına dâhil etmelerini sağladı. Bu dönemden itibaren Fransa, Rusya ve Avusturya'ya ait gemiler Ordu Limanı'na düzenli olarak uğramaya başladılar. 1870 senesinde her hafta Fevaid-i Osmaniye acentesine ait gemiler çarşamba günü İstanbul'dan hareket ederek Ordu Limanı'na uğruyor, pazar günü Trabzon'a ulaşıyor, oradan Batum'a geçerek tekrar aynı güzergâhı izleyip geri dönüyordu. Rusya acentesine ait gemiler cumartesi günü İstanbul'dan hareket edip Ordu Limanı'na uğradıktan sonra salı günü Trabzon'a gelerek ertesi günü Batum'a gidiyor, pazar günü Batum'dan hareketle yine aynı güzergâhı izleyerek geri dönüyorlardı. Fransız acentesine ait gemiler pazartesi günleri İstanbul'dan hareket edip Ordu Limanı'na uğradıktan sonra perşembe günü Trabzon'a geliyor, cumartesi günü Trabzon'dan hareketle aynı güzergâhtan geri dönüyordu. Avusturya acentesine ait gemiler ise her cuma günü İstanbul'dan hareket edip Ordu Limanı'na uğradıktan sonra pazartesi günü Trabzon'a geliyor, perşembe günü Trabzon'dan hareketle yine aynı güzergâhı izleyerek tekrar İstanbul'a dönüyordu. ${ }^{50}$

Ayrıca düzenli sefer güzergâhlarında olmasa da çok sayıda Avrupalı devletlere ait gemiler Ordu Limanı'na uğruyordu. XX. yüzyılın başlarında Ordu Limanı'na uğrayan buharlı gemilerin sayısı ve tonajları şöyledir: ${ }^{51}$

47 Önceleri "Fevaid-i Osmaniye" olan gemi acentası daha sonra "İdare-i Mahsusa" adını almıştır.

48 Ancak konuyla ilgili zaman zaman sorunlar yaşandığı görülmektedir. Örneğin Ordu kaza meclisi tarafindan Sadaret'e sunulan mazbatada; devlete ait eşya, mal ve evrakın yabancı vapurlarla gönderilmesinin uygun görülmediği için bunların bundan böyle Fevaid-i Osmaniye kumpanyası vapurlarıyla gönderilmesi gerektiği yönünde emir yayınlandığı, ancak bu emire rağmen bölgeden geçen 2 vapurdan birinin Ordu Limanı'na hiç uğramadığı ifade edilmektedir. Diğer vapurun da 30 gündür limana uğramaması ve limana uğrayan İtalyan vapuruna yayınlanan emir gereğince evrak verilememesi nedenleriyle mağduriyet yaşandığı belirtilmektedir. $\mathrm{Bu}$ nedenle Fevaid-i Osmaniye vapurlarının en azından 15 günde bir limana düzenli olarak uğraması istenmektedir. BOA, A. MKT. MHM, 349/4, 6 Şevval 1282/22 Şubat 1866.

49 Baskic1, a.g.e, s. 59.

50 XX. yüzyılın hemen başında Fransız ve Avusturya kumanyaları Ordu Limanı'nı sefer güzergâhlarından çıkardılar. TVS, 1871, s. 171.

511895 Rapport Commercial et Maritime de Kerassonde et Ordou, s. 5. (Bundan sonraki dipnotlarda Fransız Konsolos Raporları RCM kısaltmasiyla verilecektir.); TVS, 1903, s. 491; TCTV, No: 5014, s. 8. 
Tablo 2: Buharlı Gemi Sayısı ve Tonajlart

\begin{tabular}{|l|l|l|l|l|l|l|}
\hline \multirow{2}{*}{$\begin{array}{l}\text { Bağlı Bulundukları } \\
\text { Ülke }\end{array}$} & \multicolumn{2}{|c|}{$\mathbf{1 8 9 5}$} & \multicolumn{2}{c|}{$\mathbf{1 9 0 2}$} & \multicolumn{2}{c|}{$\mathbf{1 9 1 0}$} \\
\cline { 2 - 7 } & Adet & Tonaj & Adet & Tonaj & Adet & Tonaj \\
\hline Osmanlı & 152 & 153.976 & 143 & 150.785 & 372 & 373.185 \\
\hline Avusturya-Macaristan & 2 & 2.216 & 2 & 2.586 & 31 & 57.011 \\
\hline Almanya & 1 & 881 & --- & --- & 5 & 7.485 \\
\hline Ingiltere & --- & -- & 1 & 1.288 & --- & --- \\
\hline Fransa & 1 & 2.108 & 27 & 40.266 & 42 & 97.305 \\
\hline Rusya & 62 & 69.071 & 55 & 47.470 & 172 & 103.337 \\
\hline İtalya & 3 & 3.300 & 1 & 1.645 & --- & --- \\
\hline Romanya & --- & --- & --- & -- & 27 & 20.175 \\
\hline Yunanistan & --- & --- & 48 & 45.488 & 1 & 689 \\
\hline Toplam & $\mathbf{2 2 1}$ & $\mathbf{2 3 1 . 3 5 2}$ & $\mathbf{2 7 7}$ & $\mathbf{2 8 9 . 5 2 8}$ & $\mathbf{6 5 0}$ & $\mathbf{6 5 9 . 1 8 7}$ \\
\hline
\end{tabular}

Tabloda da görüldüğü gibi 1895 senesinde 221 olan Ordu Liman'ına uğrayan buharlı gemi sayıs1 1902 senesinde 277'ye 1910 senesine gelindiğinde 650'ye yükselerek toplamda üç kata yaklaşan bir artış göstermiştir. Bu artışta muhakkak ki Osmanlı şirketinin payı büyüktür. Ancak limana uğrayan Rus ve Fransız gemilerinin de artışta önemli bir payları vardır. Bunun yanında 1910 senesinden itibaren Almanya ve Romanya bandralı buharlı gemiler de Ordu Limanı'na uğramaya başlamışlardır. Buna rağmen limana uğrayan buharlı gemi sayısı Karadeniz'in diğer limanlarına uğrayan gemi sayısının altındadır. Aynı tarihte Trabzon Limanı'na 975, Giresun Limanı'na 750, Samsun Limanı'na 701 buharlı gemi uğramıştır. ${ }^{52}$

XIX. yüzyılın ikinci yarısından itibaren buharlı gemiler Karadeniz ticaretinde önemli bir paya sahip olmuşlardı. Ancak Ordu Limanı, derin bir liman olmaması ve büyük gemilerin yanaşmasına uygun iskeleye sahip olmaması gibi nedenlerle buharl gemi ticaretinden yeterince pay alamıordu. Zaten bu tür büyük gemiler büyük ticaret hacimleri için tasarlanmış ve uzun seferlere odaklanmışlardı. $\mathrm{Bu}$ nedenle buharlı gemilerin açığını yelkenli gemiler tamamlamaktaydı. Küçük bir liman olan Ordu'ya Osmanlı karasularındaki iç limanlar arasında taşımacılıkta kullanılan yelkenli gemiler de uğrayarak limanın ticaret hacminin artmasına katkıda bulunuyorlardı. $\mathrm{Bu}$ gemiler daha çok başta tuz olmak üzere kasabanın gıda ihtiyaçlarını karşılıyordu. ${ }^{53}$

1895 senesinde Ordu Limanı'na uğrayan yelkenli gemi sayısı 3 iken bu say1 1902'de 69'a 1912 senesinde ise 2.443'e yükselmiştir. 1895 senesinde yelkenli gemilerin toplam tonaj1 1000 ton iken 1902 'de bu say1 2.173, 1912 senesinde ise 6.756 ton olmuştur. ${ }^{54}$ Görüldüğü gibi Ordu Limanı'na uğrayan

52 TCTV, No: 5014, s. 8.

53 Ersin Müezzinoğlu, "Doktor Abdullah Cevdet'in Samsun, Giresun, Ordu ve Trabzon Seyahat Notlar1", Turkish Studies, C: 7, S: 3, İzmir 2012, s. 1852.

541895 RCM, s. 5; TVS, 1903, s. 491; TCTV, No: 5014, s. 8. 
yelkenli gemi buharlı sayısıyla kıyaslandığında sayısı çok azdır. Bu dönemde limana Osmanlı ve Yunanistan bandralı gemiler uğramaktaydılar. Daha sonraki dönemlerde Yunan bandralı gemiler yerini Rus bandralı gemilere bırakmıştır. 1909 senesinden itibaren de limana uğrayan yelkenli gemi sayısında önemli bir artış söz konusudur. Bu dönemde Ordu Limanı’na uğrayan yelkenli gemi sayısı Samsun ve Rize limanlarına uğrayan yelkenli sayısından fazladır. Ancak tonaj açısından bu limanların gerisinde kalmıştır. ${ }^{55}$

Ordu Limanı'na uğrayan buharlı ve yelkenli gemiler bir taraftan kaza dâhilindeki ürünleri yükleyerek yörenin Avrupa pazarlarına açılmasını sağlarken diğer taraftan Avrupa'dan getirdikleri malları indirerek halkın ihtiyaçlarını karşılıyorlardı. Bu dönemde kazadan ihraç edilen ürünlerin hemen tamamını hayvansal ve tarımsal ürünler oluşturmaktaydı. Yurt dışına ihraç edilen tarım ürünleri daha çok yörede üretimi fazla olan mısır, fasulye, findık, ceviz, arpa, buğday, yulaf, keten, kendir ve çeşitli meyvelerdi. Keçi ve koyun derisi, yün, balık yağı, yumurta ve balmumu da ihraç edilen ürünler arasındaydı. Ayrıca küçük el tezgâhlarında yerli ustalar tarafından yapılan ağaç tekne ve kürekler de yurt dışına satılmaktaydı. XX. yüzyılın başlarında Ordu Limanı'ndan yapılan ihracatın ürünlere dağılımı, aşağıdaki tablodaki gibiydi: ${ }^{56}$

Tabloya bakıldığında Ordu Limanı'ndan ihraç edilen malların tamamını tarımsal ve hayvansal ürünlerin oluşturduğu görülmektedir. 1910'da 81.720 sterlin olan ihracatın sonraki senelerde 130.000 sterlinin üzerine çıkmıştır. Bu ihracatta en önemli kalemi findık oluşturmaktadır. 1910' da findık ihracatı toplam ihracatın \% 61 'ini oluştururken, bu oranın daha sonraki senelerde $\% 74$ seviyelerinde olduğu görülmektedir. 1910 senesindeki oranın \% 61 olmasındaki sebep büyük ihtimalle o seneki rekolte düşüklüğünden kaynaklanmaktadır. ${ }^{57}$

Kaza dâhilinde üretilen ürünlerin bir bölümü Osmanlı iç piyasasına, bir bölümü de Avusturya-Macaristan, Fransa, Rusya, Almanya, Belçika, İngiltere, İtalya ve Balkan ülkelerine satılıyordu. Özellikle bölgede üretilen tütünler Misır'ın İskenderiye, Hollanda'nın Rotterdam ve Amsterdam, Almanya'nın Hamburg, Dresden ve Bremen, İngiltere ve kolonilerindeki Londra, Kibrıs, Aden ve Malta, Yunanistan'ın Sisam, Belçika'nın Antwerp, Amerika Birleşik Devletleri'nin Newyork, İtalya'nın Trieste ve Fransa'nın Marsilya limanlarına

551910 senesinde Trabzon Limanı'na gelen 6.389 yelkenli geminin toplam tonaj1 29.571 'dir. Giresun Limanı'na gelen 4.260 yelkenli geminin toplam tonaj1 13.859'dur. Samsun Limanı'na gelen 1.653 yelkenli geminin toplam tonaj1 10.569 'dur. Rize Limanı'na gelen 1.987 yelkenli geminin toplam tonaj 10.856 'dır. TCTV, No: 5014 , s. 8.

56 TVS, 1903, s. 464-465; TCTV, No: 4740, s. 15-16.

57 Nitekim benzer bir durum 1899 senesinde de yaşanmıştır. 1901 senesinde toplam 10.161.100 kıyye ürün ihracatından 10.518.948 kuruş gelir elde edilmiştir. Bu rakam bir önceki yılın rakamlarından 6.043.210 kıyye ve 5.732.940 kuruş fazladır. Bu fazlalı̆ı̆ın sebebi ise mısır buğdayı, fasulye ve buğdayın 1899 senesinde önceki senelere göre çok daha az olmasıdır. TVS, $1901,225$. 
ihraç ediliyordu. ${ }^{58} 1909,1910$ ve 1912 yıllarında Ordu Limanı'ndan yabancı ülkelere yapılan ihracat rakamları şöyledir: (Tablo 4) $)^{59}$

Tablo 3: Ürünlere Göre İhracat Rakamları

\begin{tabular}{|l|l|l|l|}
\hline Ürün Adı & $\begin{array}{l}\mathbf{1 9 1 0} \\
\text { (Sterlin) }\end{array}$ & $\begin{array}{l}\mathbf{1 9 1 1} \\
\text { (Sterlin) }\end{array}$ & $\begin{array}{l}\mathbf{1 9 1 2} \\
\text { (Sterlin) }\end{array}$ \\
\hline Fasulye & 2.560 & 2.670 & 1.370 \\
\hline Kemik & 30 & 20 & --- \\
\hline Tahıl (Buğday, Arpa, Yulaf) & 140 & 160 & --- \\
\hline Yumurta & 9.660 & 9.790 & 12.300 \\
\hline Fındık & 49.980 & 100.300 & 97.000 \\
\hline Balık, Balık Yağı & 120 & 150 & 120 \\
\hline Meyve, Kuruyemiş, Sebze & 4.100 & 4.350 & 4.100 \\
\hline Keten ve Kenevir Tohumu & 530 & 650 & 530 \\
\hline Post, Deri & 320 & 350 & 420 \\
\hline Domuz Yağı & 400 & 420 & 430 \\
\hline Siğır Ürünleri & 60 & 70 & 60 \\
\hline Koyun & 430 & 530 & 540 \\
\hline Tütün & 780 & 850 & 1.050 \\
\hline Balmumu & 1.340 & 1.460 & 1.530 \\
\hline Yün ve Tiftik & 11.010 & 10.220 & 10.370 \\
\hline Diğer Ürünler & 1.080 & 1780 & 2.530 \\
\hline Toplam & $\mathbf{8 1 . 7 2 0}$ & $\mathbf{1 3 3 . 7 7 0}$ & $\mathbf{1 3 1 . 7 4 0}$ \\
\hline & & & \\
\hline
\end{tabular}

Tablodan da görüleceği üzere bu tarihlerde Ordu Limanı'ndan gerçekleştirilen ihracatın \% 73'ü Avrupa ülkelerine olmuştur. En çok mal satılan ülke Avusturya-Macaristan, en az mal satılan ülkeler Misır ve Yunanistan'dır. 1910'dan sonra ise bu ülkeler Ordu pazarından çıkarken, Almanya Ordu pazarına girmiştir. Bu tarihlerde Ordu Limanı'ndan yapılan ihracat Trabzon, Samsun ve Giresun gibi Karadeniz'in önemli limanlarının gerisindedir. Ancak Rize ve Tirebolu gibi küçük limanların önündedir.

58 TCTV, No: 5313, s. 10.

59 TCTV, No: 4740, s. 11; TCTV, No: 5014, s. 10, TCTV, No: 5166, s. 11-12.

60 1909-10 tarihli İngiliz konsolosluk raporunda belirttiği üzere bu tarihte 1 sterlin: 110 altın veya 119 gümüş kuruşa denk gelmektedir. TCTV, No: 4740, s. 4. 
Tablo 4: Ülkelere Göre İhracat Rakamları

\begin{tabular}{|l|l|l|l|}
\hline Ülkeler & $\begin{array}{l}\mathbf{1 9 1 0} \\
\text { (Sterlin) }\end{array}$ & $\begin{array}{l}\mathbf{1 9 1 1} \\
\text { (Sterlin) }\end{array}$ & $\begin{array}{l}\mathbf{1 9 1 2} \\
\text { (Sterlin) }\end{array}$ \\
\hline İngiltere & 880 & 1.520 & 2.100 \\
\hline Mısır & 2.900 & --- & --- \\
\hline Avusturya Macaristan & 32.000 & 51.210 & 50.100 \\
\hline Balkan Ülkeleri & 2.040 & 2.760 & --- \\
\hline Fransa & 16.950 & 20.150 & 20.670 \\
\hline Almanya & --- & 1.970 & 2.090 \\
\hline Belçika & 1.400 & 1.620 & 1.530 \\
\hline Yunanistan & 2.430 & --- & --- \\
\hline İtalya & 5.140 & 980 & 3.400 \\
\hline Rusya & 3.520 & 6.090 & 6.380 \\
\hline Diğer Ülkeler & 2.150 & 3.260 & 2.620 \\
\hline Yabancı Ülkeler Toplamı & 71.130 & 89.560 & 88.890 \\
\hline Osmanlı Toplamı & 11.470 & 44.210 & 42.850 \\
\hline Genel Toplam & $\mathbf{8 2 . 6 0 0}$ & $\mathbf{1 3 3 . 7 7 0}$ & $\mathbf{1 3 1 . 7 4 0}$ \\
\hline
\end{tabular}

Limandan mal almaya gelen gemiler aynı zamanda kasabaya mal getiriyorlardı. Ordulu bazı tüccarlar yelkenli gemilerle Kafkasya, Romanya ve Kırım'a giderek, oralardan şeker, gaz, un gibi tüketim maddelerini satın alıp Ordu'ya getirerek kaza dâhilinde satıyorlardı. ${ }^{61} \mathrm{XX}$. yüzyılın başlarında Ordu limanından gerçekleştirilen ithalat rakamları şöyledir. ${ }^{62}$

Tablo 5: Ürünlere Göre Ithalat Rakamları

\begin{tabular}{|l|l|l|l|}
\hline Ürün Adı & $\begin{array}{l}\mathbf{1 9 1 0} \\
\text { (Sterlin) }\end{array}$ & $\begin{array}{l}\mathbf{1 9 1 1} \\
\text { (Sterlin) }\end{array}$ & $\begin{array}{l}\mathbf{1 9 1 2} \\
\text { (Sterlin) }\end{array}$ \\
\hline Mum & 110 & 120 & 150 \\
\hline Kimyasal, İlaç, Boya & 610 & 720 & 700 \\
\hline Kahve & 1.360 & 1.420 & 1.120 \\
\hline Yün ve Pamuk Ürünleri & 69.440 & 79.370 & 71.510 \\
\hline Cam, Çanak, Çömlek & 400 & 490 & 310 \\
\hline Ateşli Silahlar & 50 & 80 & --- \\
\hline Un & 7.170 & 8.230 & 7.630 \\
\hline Meyve, Fındık, Sebze & 530 & 610 & 520 \\
\hline Donanım ve Demir Eşya & 3.630 & 3.720 & 4.360 \\
\hline İşlenmiş Deri & 2.070 & 2.350 & 2.120 \\
\hline Makineler (Dikiş Makinesi vb) & 90 & 110 & 150 \\
\hline Maden Ürünleri (Demir, Çelik, Bakır vb) & 2.460 & 2.780 & 2.210 \\
\hline
\end{tabular}

61 Sitk1 Çebi, Salnamelerde Ordu, Ordu 2003, s. 93.

62 TVS, 1903, s. 464-465; TCTV, No: 4740, s. 12-13. 


\begin{tabular}{|l|l|l|l|}
\hline Zeytin, Zeytinyağı & 3.140 & 3.220 & 3.050 \\
\hline Petrol, Petrol Gazı & 1.810 & 2.070 & 1.870 \\
\hline Konserve Yiyecek & 790 & 820 & 940 \\
\hline Pirinç & 7.050 & 8.420 & 6.980 \\
\hline Çuval, Çadır Bezi, Balmumu Kumaş vb. & 90 & 120 & 160 \\
\hline Tuz & 5.080 & 6.350 & 5.390 \\
\hline Sabun & 3.040 & 3.420 & 3.130 \\
\hline Çeşitli İçki (Şarap, Bira) & 850 & 760 & 680 \\
\hline Şeker & 6.940 & 7.350 & 6.130 \\
\hline Çay & 50 & 60 & 80 \\
\hline Buğday, Arpa, Yulaf & 2.180 & 2.780 & 2.560 \\
\hline İplik ve Dokuma Giyecekler & 570 & 630 & 1.460 \\
\hline Tütün & --- & --- & 1.200 \\
\hline Kâ̆ğt & --- & --- & 140 \\
\hline Lastik & --- & --- & 1.300 \\
\hline Fes & --- & --- & 960 \\
\hline Kibrit & --- & --- & 2.800 \\
\hline Kereste & --- & --- & 1.400 \\
\hline Parfüm & --- & --- & 110 \\
\hline Diğer ürünler & 13.430 & 12.540 & 9.690 \\
\hline Toplam & $\mathbf{1 3 9 . 7 3 0}$ & $\mathbf{1 4 9 . 1 9 0}$ & $\mathbf{1 4 1 . 4 7 0}$ \\
\hline & & & \\
\hline & \multicolumn{2}{|l}{}
\end{tabular}

Tabloya bakıldığında Ordu Limanı'ndan en çok mal ithalinin yapıldığı ülkenin İngiltere olduğu, onu Avusturya Macaristan ve Rusya'nın izlediği görülmektedir. İthalatın en az gerçekleştiği ülkeler başta Yunanistan ve Belçika'dır. Limandan gerçekleştirilen ithalatın ihracata oranı \% 23'tür. İthal edilen mallar daha çok işlenmiş ya da yarı işlenmiş mallardır. Bu mallar arasında ise en önemli kalemi yün ve pamuk ürünleri oluşturmaktadır. $\mathrm{Bu}$ ürünler toplam ithalatın hemen hemen yarısına karşıllk gelmektedir. Bunun yanında sigara, şarap, sabun, zeytinyağı, şeker ve kahve gibi o döneme göre lüks sayılabilecek tüketim maddeleri de ithal edilen mallar arasındadır. 1912 senesinden itibaren de parfüm, tütün, kâğıt, lastik, kibrit ve kereste gibi ürünler ithal edilmeye başlanmıştır.

İthal edilen mallar arasında en çok dikkat çeken kalem makinedir. Diğer kalemlerin hepsi tüketime yönelik mallar iken makine ithalatı üretime yöneliktir. İthal edilen dikiş makineleri bölgede havlu ve peştamal gibi şeylerin imalinde kullanılıyordu. Yani küçük de olsa kasabada sanayinin ve işlenmiş ürünlerin artırılmasına katkı sağlamak amacını güdüyordu. Nitekim bu makinelerde üretilen havlu ve peştamallar kaza dâhilinde satıliyordu. ${ }^{63}$ İthal edilen bu makineler yöredeki dokumacıllk sektörünün ve sanayinin gelişmesi için önem arz ediyordu.

63 Çebi, a.g.e, s. 82. 


\section{Sonuç}

Ordu Limanı, zamanla uluslararası ticaret yapan gemilerin sefer güzergâhlarına dâhil olmuştur. Haftanın değişik günlerinde limana uğrayan gemiler şehir ticaretinin gelişmesini ve canlı kalmasını sağlamışlardır. Daha önceleri içe kapanık ekonomik faaliyetler sürdüren Ordu kazası böylece dış piyasalarla tanışmıştır. Kaza ekonomisi bu dönemde bir hayli canlanmıştır. Limandaki ticari canlılık Ordu kazasının ticaret potansiyelinin artmasına, şehrin büyümesine ve dünya ticaretiyle eklemlenmesine katkıda bulunmuştur.

Deniz ticaretinin önem kazanması ve buharlı gemilerin öne çıkması, sahil şehirlerinde yeni liman ve iskelelerin yapılmasını zorunlu kılmıştır. Trabzon vilayetinin merkez sancağına bağlı önemli kazalardan biri olan Ordu'da da XIX. yüzyılın sonlarında bu gelişmelere paralel olarak önce ahşap bir iskele yapılmıştır. İskelenin çevresine daha sonra acente ve idari binalar eklenmiştir. Böylece modern liman imkânlarından mahrum da olsa burası bir liman haline gelmiştir.

$\mathrm{Bu}$ süreçte diğer limanlarda görülen benzer sorunlar burada da yaşanmıştır. Liman çevresinin imara açılmak istenmesi ve asayiş sorunları bunların başında gelmektedir. Özellikle, yapılaşma sorunu kayıkçı esnafını olumsuz etkilemiştir. Limanların en aktif çalışanları olan kayıkçı esnafi mağdur olmuştur. Bu duruma engel olmak için mücadele içine girmişlerdir.

İstatistikî verilere bakıldığında Ordu Limanı'nın bir ihracat limanı olduğunu söylemek mümkündür. Ordu Limanı, ticarî olarak Rize ve Tirebolu gibi diğer Karadeniz limanlarının önünde yer almıştır. Ancak yine de Karadeniz'in büyük limanları olarak nitelendirilen Samsun, Trabzon ve Giresun limanlarının gerisindedir. Bununla birlikte Ordu Limanı'nın buharlı gemi şirketlerinin sefer listesine girmesi ve iç bölgeler için birer ihracat limanı haline gelmesi bu limanların ticaretini olumsuz etkilemiştir. 


\section{EKLER}

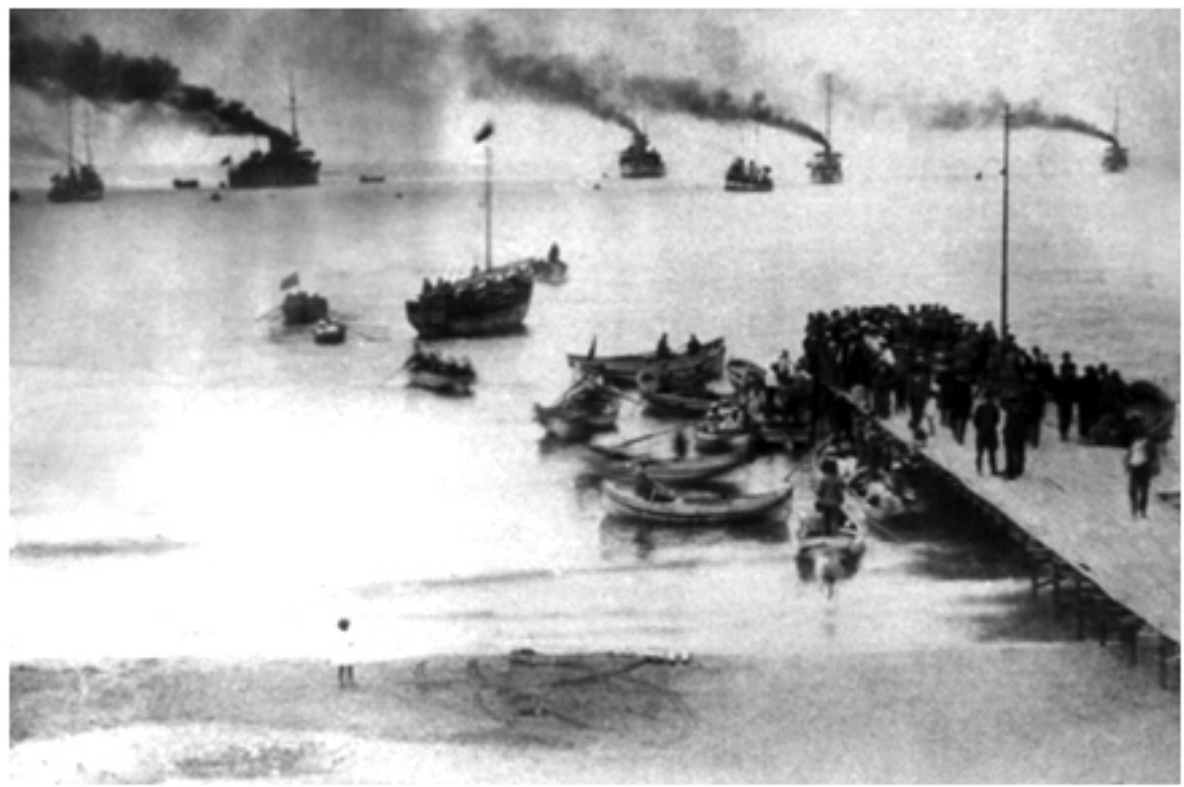

Ordu İskelesinden Genel Bir Görünüm

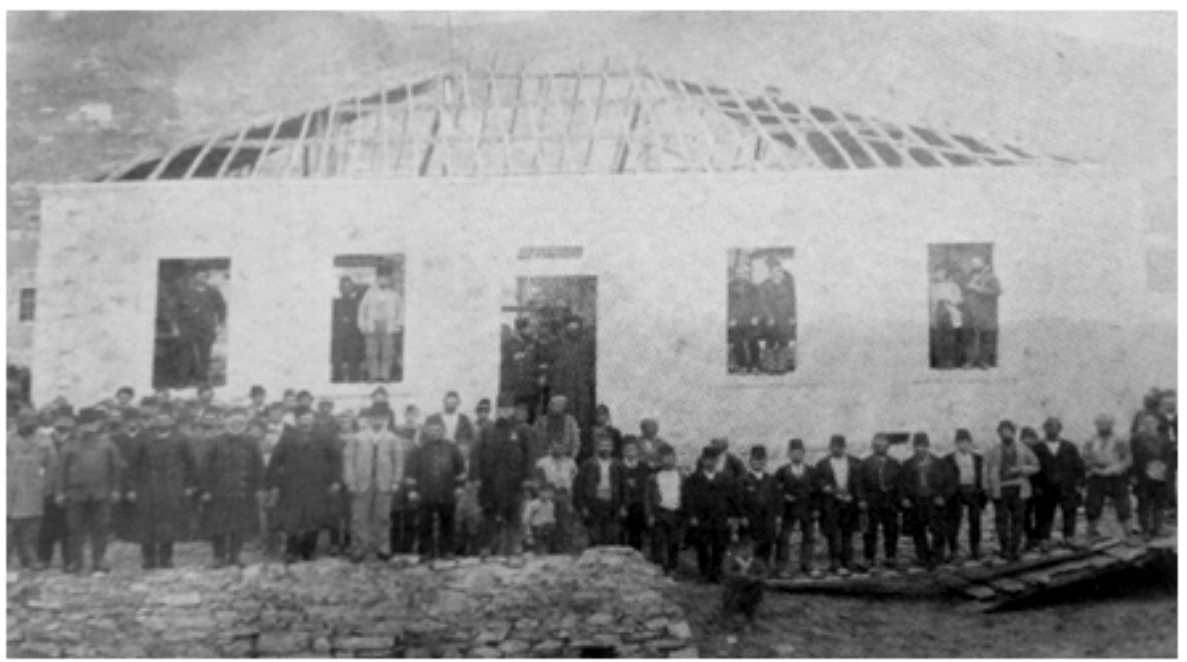

Ordu Liman Dairesi ve Acentehane Binasının Yapımı 


\section{KAYNAKLAR}

\section{Arşiv Belgeleri}

Başbakanlık Osmanlı Arşivi (BOA)

BOA, A. MKT. MHM, (Sadâret Mühimme Kalemi Evrakı).

No: 349/4, 6 L 1282.

BOA, BEO, (Bâb-ı Âlî Evrak Odası Arşivi Evrakı).

No: 1728/129541, 20 C 1319; 4291/321771, 17 B 1332.

BOA, DH. EUM.5.Şb, (Dâhiliye Nezareti Emniyet-i Umumiye Müdüriyeti 5. Şube Evrakl).

No: 17/13, 07 Za 1333.

Şube Evrakı).

BOA, DH. EUM.6.Şb, (Dâhiliye Nezareti Emniyet-i Umumiye Müdüriyeti 6.

No: 17/84, 29 N 1335.

BOA, DH. ID, (Dâhiliye Nezareti İdari Kısım Evrakı).

No: 52/6, 07 Ca 1309.

BOA, DH. MKT, (Dâhiliye Nezareti Mektubi Kalemi Evrakı).

No: 1482/26, 18 Ca 1305; 2367/105, 04 Ra 1318; 1510/38, 20 N 1305; 1982/75, 10 M /1310; 2731/34, 15 M 1327; 1933/83, 17 Ş 1309; 1938/13, 29 Ş 1309.

BOA, DH. ŞFR, (Dâhiliye Nezareti Şifre Kalemi Evrakı).

No: 525/78, 04 Te 1332; 555/93, 20 May1s 1333.

BOA, I. ŞD, (İrade Şûra-yı Devlet Evrakı).

No: 69/4086, 16 L 1301.

BOA, ŞD, (Şûra-yı Devlet Arşivi Evrakı).

No: 1841/29, 09 Za 1321; 1849/14, 11 R 1314.

BOA. Y. PRK. ASK, (Yıldız Perakende Askeri Maruzat Evrakl).

No: 53/101, 19 B 1306

BOA, Y. PRK. DH, (Yıldız Perakende Dâhiliye Nezareti Maruzatı Evrakı).

No: 1/81, 07 R 1302.

Ingiliz ve Fransiz Konsolosluk Raporlart

[Diplomatic and Consular Reports, Turkey. Report on the Trade and Commerce of the Trebizond Vilayet (TCTV)].

TCTV, No: 4315; TCTV, No: 4740; TCTV, No: 5014; TCTV, No: 5166; TCTV, No: 5313.

Rapport Commercial et Maritime de Kerassonde et Ordou (RCM).

1895 RCM.

\section{Kitap ve Makaleler}

ATMACA, Sezar, “Çapar Kaybolan Tekne”, Atlas, 231, 2012, s. 56-60.

AYGÜN, Necmettin, “Osmanlı Devleti'nin Son Zamanlarında Karadeniz'in Güney Kesiminde İktisadî Faaliyetler”, Karadeniz Araştırmaları, 6/23, 2009, s. 41-76.

BASKICI, Murat, 1800-1914 Yillarında Anadolu'da İktisadi Değişim, Turhan Kitabevi, Ankara 2005.

BEYDİLLI, Kemal, "Karadeniz'in Kapalılığı Karşısında Avrupa Küçük Devletleri ve "Miri Ticaret" Teşebbüsü", Belleten, C: 55, S: 214, Aralık 1991, s. 687755. 
BOARDMAN, John, The Greeks Overseas, London 1988.

ÇADIRCI, Musa, Tanzimat Döneminde Anadolu Kentlerinin Sosyal ve Ekonomik Yapısı, TTK Yayınları, Ankara 1997.

ÇEBİ, Sitk1, Salnamelerde Ordu, Ordu 2003.

DAŞ, Mustafa-Töreli, Türkmen, "XIV. ve XIX. Yüzyıllarda Batılı Seyyahların Gözüyle Karadeniz Ticareti", Tarih Boyunca Karadeniz Ticareti ve Canik-Samsun, Samsun 2013, s. 843-848.

DEVELLİĞLU, Ferid, Osmanlıca-Türkçe Ansiklopedik Lûgat, Aydın Kitabevi, Ankara 2010.

EKINCİ, İlhan, "XIX. Yüzyılda Osmanlı Deniz Ticaretinde Değişim ve Tepkiler”, Tarih İncelemeleri Dergisi, C: 21, S: 2, İzmir 2006, s. 37-54.

FIDAN, Murat, “1797-1800 Tarihlerinde Osmanl1-Rusya Arasında Karadeniz Üzerinden Gerçekleşen İhracat ve İthalat (87/5 Numaralı Rusya Ahkâm Defterine Göre)", Tarih Araştırmaları Dergisi, C: 28, S: 45, Ankara 2009, s. 63-84.

MURAT, Uluskan, "Üsküdar Kayıkçıları (XVIII. Yüzyıl)", Üsküdar Sempozyumu V-Bildiriler, (1-5 Kasım 2007), C: 1, Üsküdar Belediyesi Yayınları, İstanbul 2008, s. 246.

MÜEZZİNOĞLU, Ersin, "Doktor Abdullah Cevdet'in Samsun, Giresun, Ordu ve Trabzon Seyahat Notları”, Turkish Studies, C: 7, S: 3, İzmir 2012, s. 1843-1857.

SAYLAN, Kemal, 1868-1914 Döneminde Ordu Kazası, KTÜ Sosyal Bilimler Enstitüsü Yayımlanmamış Yüksek Lisans Tezi, Trabzon 2007.

ŞEMSEDDIN Sami, Kamus'ul Alam, C: 2, Ankara 1996.

ŞAKİR Şevket, Trabzon Tarihi, Haz. İsmail Hacıfettahoğlu, Ankara 2001.

Trabzon Vilayet Salnameleri, [Trabzon Vilayeti Matbaas1, 1286/18691322/1904: (TVS)]. TVS, 1871; TVS, 1888; TVS, 1892; TVS, 1901; TVS, 1902; TVS, 1903; TVS, 1904.

YILDIZ, Adnan, Osmanlı Belgelerinde Ordu, Ordu Valiliği Yayınları, İstanbul 2013.

YILMAZ, Özgür, "Buharlı Gemi Çağında Karadeniz'de Avrupa Denizciliğii”, Karadeniz Sosyal Bilimler Dergisi, S: 25, Ankara 2014, s. 45-64.

Batılı Seyyahlara Göre Trabzon (1808-1878), Karadeniz Teknik Üniversitesi Sosyal Bilimler Enstitüsü Yayımlanmamış Yüksek Lisans Tezi, Trabzon 2006.

YİĞİT, Ali Ata, "Tarihi Süreci Işığında Kelkit Vadisi ve Sivas-ŞebinkarahisarGiresun Ticaret Yolu”, Orta Karadeniz Kültürü Sempozyumu, Ankara, 2005, s. 479494.

YÜKSEL, Ayhan, "Vona’nın Sancak Merkezi Yapılma Girişimi (1885)”, Doğu Karadeniz Araştırmaları, Kitabevi Yayınları, İstanbul 2005, s. 115-118. 